\title{
Aphid Species and Population Dynamics Associated with Strawberry
}

\author{
D Bernardi ${ }^{1}$, ES Araujo ${ }^{2}$, MaC Zawadneak $^{2}$, M Botton $^{3}$, AF Mogor $^{4}, \mathrm{MS} \mathrm{Garcia}^{5}$ \\ ${ }^{1}$ Depto de Entomologia e Acarologia, ESALQ/USP, University of São Paulo, Piracicaba, SP, Brasil \\ ${ }^{2}$ Depto de Patologia Básica, Univ Federal do Paraná, Curitiba, PR, Brasil \\ ${ }^{3}$ Embrapa Uva e Vinho, Bento Gonçalves, RS, Brasil \\ ${ }^{4}$ Depto de Fitotecnia, Univ Federal do Paraná, Curitiba, PR, Brasil \\ ${ }^{5}$ Depto de Fitossanidade, Univ Federal de Pelotas, Pelotas, RS, Brasil
}

\section{Keywords}

Fragaria×ananassa, population density, strawberry aphid, strawberry root aphid

\section{Correspondence \\ D Bernardi, Depto de Entomologia e Acarologia, ESALQ/USP, University of São Paulo, Av. Pádua Dias, 11, 14318- 900 Piracicaba, SP, Brasil; dbernardi@ yahoo.com.br}

Edited by André L Lourenção - IAC

Received 21 March 2013 and accepted 4 July 2013

Published online: 18 September 2013

(C) Sociedade Entomológica do Brasil 2013

\begin{abstract}
Aphids are among the major pests associated with strawberries in Southern Brasil. In this study, we identified the main species that occur in strawberry fields in the states of Paraná and Rio Grande do Sul, Brasil. We also compared the effectiveness of different sampling methods and studied the population dynamics of aphid species during two strawberry crop cycles in the municipality of Pinhais, state of Paraná, Brasil. Chaetosiphon fragaefolii (Cockerell) and Aphis forbesi Weed were the main species associated with strawberry. The method of hit plant and the Möericke trap showed equal effectiveness to capture wingless and winged insects. The peak population of aphids in the state of Paraná occurred from September to November. This information can help producers to implement strategies to monitor and control the major aphid species that occur in strawberry culture.
\end{abstract}

\section{Introduction}

Cultivation of strawberries (Fragaria $\times$ ananassa Duchesne) is an important economic activity for small- and mediumsized farms in different producing regions, especially in Southern Brasil (Ferla et al 2007). However, constant interventions to control pests and diseases are required (Fadini et al 2004) to satisfy the market demand for defect-free fruits. Aphids stand out among arthropod pests that occur in strawberry culture. Large populations of these insects intensify sap sucking, favoring the development of sooty mold (Capnodium sp.) resulting in reduced photosynthesis, production, and fruit quality (Krczal 1982, Rondon et al 2005, Cédola \& Greco 2010). Moreover, aphids are vector of viruses (Rondon \& Cantcliffe 2004, Rondon et al 2005, Cédola \& Greco 2010).

Although aphids are considered important pests in strawberry, little is known on the species that occur in the different regions of Brasil. Furthermore, many studies show a national divergence regarding aphid species and their scientific nomenclature. Among the species reported in Southern Brasil, Chaetosiphon fragaefolii (Cockerell) (Costa et al 1993) is predominant, but it was also reported as Pentatrichopus fragaefolii (Cockerell) and Capitophorus fragaefolii (Cockerell) (Salles 2003). Similarly, Aphis forbesi (Weed) was also cited as Cerosipha forbesi (Weed) (Salles 2003). According to Remaudière et al (1997), the genera Pentatrichopus and Capitophorus cited by Hodson (1937) and Salles (2003) are no longer reported in the literature or even as synonymy. Also, the genus Cerosipha cited in the studies by Salles (2003) is considered a synonym for the genus Aphis (Remaudière et al 1997).

Accordingly, to implement an integrated pest management program for aphid pests, it is crucial to know the species and their population dynamics to identify population peaks and, therefore, define the best time to employ control measures (Miller \& Foottit 2009, Henz 2010). It is critical to determine the best sampling method during the strawberry crop cycle to obtain effective monitoring of aphid pests.

Currently, monitoring is performed randomly by observing the presence of aphids on plants in the plant beds (visual identification). Due to the gregarious habit of aphids, this monitoring technique does not show the actual population 
density of the pest in the field once colonies of these insects are formed on the underside of strawberry leaves or plant crown, hindering visual identification. Therefore, studies on new effective monitoring methods are necessary to monitor aphids in strawberry, allowing a more accurate density estimate of the pest population in the field. Thus, the objective of this study was to identify the main aphid species associated with strawberry culture in the states of Paraná and Rio Grande do Sul in Brasil to determine the best sampling method of aphid pests and to evaluate the population dynamics of aphid species in strawberry.

\section{Material and Methods}

\section{Aphid species associated with strawberry culture}

The aphid species associated with strawberry culture in the states of Rio Grande do Sul and Paraná, Brasil, were surveyed during two crop cycles (2009/2010 and 2010/2011). Samples were collected in commercial cultivations of strawberry grown in low-tunnel system.

In the state of Rio Grande do Sul, the study was conducted in 49 commercial areas of strawberry; in the municipalities of Bento Gonçalves (two areas), Caxias do Sul (eight areas), Farroupilha (three areas), Flores da Cunha (three areas), Bom Princípio (eleven areas), Feliz (three areas), Ipê (nine areas), Pelotas (six areas), Turuçu (two areas), and São Lourenço do Sul (two areas) from August 2009 to August 2010. Every month, we collected five leaves from the top of the plant and five petioles of the crown region per plant sampled from 10 random points in each crop totaling 490 samples during the study period. The aphids collected were kept on their own leaves or petioles and transported to the lab in plastic bags ( $3 \mathrm{~L}$ ), where winged and wingless insects were screened and preserved in $70 \%$ ethanol for later identification.

In the state of Paraná, aphid species were monitored only in the municipality of Pinhais, from March 2010 to March
2011, using chromotropic Möericke traps and the method of hit plant, as proposed by van Driesche et al (1998). Traps were deployed in stage of plant growth (first sprouts). The average size of farms was approximately of 0.3 ha. The experimental design was a randomized block in factorial, with treatments consisting of four strawberry cultivars (Albion, Camarosa, Camino Real, and Ventana). During the crop cycle, insecticide was not sprayed for pest control and the management of invasive plants was performed manually. Data on temperature and precipitation were obtained from the Meteorological Station of Pinhais, state of Paraná.

The chromotropic Möericke traps were made with plastic bottles $(2 \mathrm{~L})$ by making a rectangular cut $(17 \times 14 \mathrm{~cm})$ in the longitudinal direction. The inside of the bottles was painted in yellow and positioned horizontally at the center of the plots among leaves of the strawberry plants at the same height of the plant, transverse to the direction of plots, and filled with saturated water $(1 \mathrm{~L})$ and detergent $(200 \mathrm{~mL})$. The trap contents were collected weekly with a 0.2-mm sieve and the solution was replaced.

The method of plant hit was carried out with three shakes in the shoot of strawberry plant to capture the aphids (winged and wingless) in a plastic tray $(0.25 \times 0.30 \times 0.5 \mathrm{~m})$ lined with white ethyl vinyl acetate paper dampened with water and detergent solution to prevent the escape of insects. The sampling was carried out weekly at random in four strawberry plants along the plant beds.

\section{Species identification}

Aphid specimens were prepared on slides following Martin (1983) and identified using taxonomic keys (Costa et al 1993, Blackman \& Eastop 2000). After species identification, we determined the occurrence rates by using faunistic analysis (Abreu \& Nogueira 1989). The aphids captured in Paraná by using the different sampling methods and cultivars were subjected to analysis of variance and means were compared by using the Tukey's test at $0.05 \%$ probability (SAS Institute 2009).

Table 1 Aphid species collected from strawberry plants with data on occurrence, dominance and Palma classification. Municipality of Pinhais, state of Paraná.

\begin{tabular}{|c|c|c|c|c|c|}
\hline Species & $\mathrm{O}(\%)$ & PCO & $\mathrm{D}(\%)$ & PCD & PGC \\
\hline Chaetosiphon fragaefolii & 52.0 & C & 68.1 & DM & C \\
\hline Aphis forbesi & 25.0 & $A C$ & 14.5 & $\mathrm{DM}$ & I \\
\hline Aphis gossypii & 19.1 & $A C$ & 16.2 & $\mathrm{DM}$ & I \\
\hline Myzus persicae & 0.3 & $A C$ & 0.2 & $A C$ & $\mathrm{R}$ \\
\hline Tetraneura nigriabdominalis & 3.60 & $A C$ & 1.0 & $\mathrm{AC}$ & $\mathrm{R}$ \\
\hline
\end{tabular}

(O\%) rate of occurrence for aphid species, PCO Palma Classification for occurrence ( $A C$ accidental, $A S$ accessory, $C$ constant), $D(\%)$ rate of dominance for aphid species, $P C P$ Palma Xlassification for predominance ( $A C$ accidental, $A S$ accessory, DM dominant), $P G C$ Palma General classification ( $C$ common, I intermediate, $R$ rare). 
Table 2 Aphid species collected from strawberry plants with data on occurrence, dominance and Palma classification. Municipalities in the state of Rio Grande do Sul.

\begin{tabular}{lllll}
\hline Species & O(\%) & PCO & D (\%) & PCD \\
\hline Chaetosiphon fragaefolii & 81.6 & C & 68.5 & PGC \\
Aphis forbesi & 18.4 & AC & 31.5 & C \\
\hline
\end{tabular}

$O \%$ rate of occurrence for aphid species, $P C O$ Palma Classification for occurrence ( $A C$ accidental, $A S$ accessory, $C$ constant), $D(\%)$ rate of dominance for aphid species, $P C D$ Palma Classification for predominance ( $A C$ accidental, $A S$ accessory, DM dominant), PCG Palma General classification ( $C$ common, I intermediate, $R$ rare).

\section{Results and Discussion}

Diversity of aphid species associated with strawberry culture in the states of Rio Grande do Sul and Paraná

We identified five aphid species associated with the strawberry culture in the municipality of Pinhais, state of Paraná: Chaetosiphon fragaefolii (Cockerell), A. forbesi Weed, Aphis gossypii Glover, Myzus persicae (Sulzer) and Tetraneura nigriabdominalis (Sasaki; Table 1). However, when the same study was carried out in different municipalities in the state of Rio Grande do Sul, we observed only two aphid species instead: C. fragaefolii and A. forbesi (Table 2). Chaetosiphon fragaefolii was predominant in both study sites $(68.1 \%$ Pinhais and $81.63 \%$ in Rio Grande do Sul). Similar values were obtained for $A$. forbesi, with intermediate occurrence of $14.5 \%$ in Pinhais and $18.3 \%$ in Rio Grande do Sul. Aphis gossypii and $M$. persicae showed intermediate occurrence, while $T$. nigriabdominalis had rare occurrence in Pinhais (Table 1). These species were not identified in the study sites in Rio Grande do Sul (Table 2).

We observed greater diversity of aphids associated with strawberries in the municipality of Pinhais when compared to the study conducted in Rio Grande do Sul, as strawberry is cultivated under organic production system in Pinhais. Organic production systems are known to be ecologically balanced and lead to an increased diversity of species (Miñarro et al 2009). Furthermore, the non-use of insecticides in the area allowed the establishment of new pests that would be otherwise eliminated or kept at low population densities by chemical applications (Zehnder et al 2007).

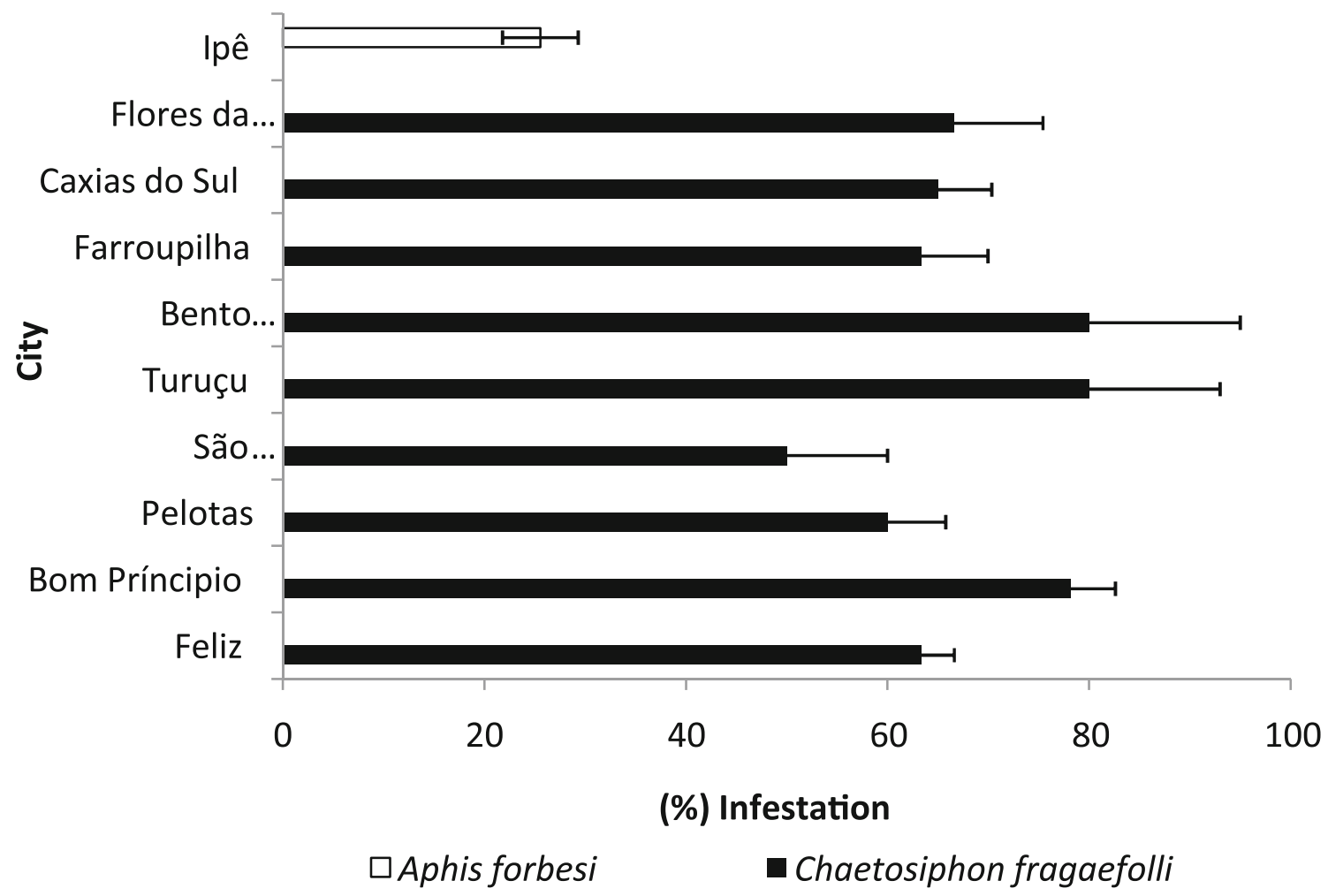

Fig 1 Rate of aphid infestation in commercial strawberry cultures in municipalities in the state of Rio Grande do Sul. 
Table 3 Weekly number $(\mathrm{X} \pm \mathrm{EP})$ of aphids (wingless + winged) captured in strawberry cultivars in the municipality of Pinhais, state of Paraná.

\begin{tabular}{llll}
\hline Cultivars & Aphis gossypii & Aphis forbesi & Chaetosiphon fragaefolii \\
\hline Albion & $0.631 \pm 0.254 \mathrm{aB}$ & $0.548 \pm 0.125 \mathrm{aB}$ & $2.618 \pm 0.529 \mathrm{aA}$ \\
Camino Real & $0.381 \pm 0.095 \mathrm{aB}$ & $0.598 \pm 0.069 \mathrm{aB}$ & $1.847 \pm 0.309 \mathrm{aA}$ \\
Camarosa & $0.447 \pm 0.104 \mathrm{aB}$ & $0.601 \pm 0.203 \mathrm{aB}$ & $2.244 \pm 0.461 \mathrm{aA}$ \\
Ventana & $0.319 \pm 0.104 \mathrm{aB}$ & $0.515 \pm 0.060 \mathrm{aB}$ & $1.826 \pm 0.405 \mathrm{aA}$ \\
\hline
\end{tabular}

Means followed by lowercase letters in the columns and uppercase letters in the rows did not differ in the Tukey's test $(P \leq 0.05)$.

We observed high infestation with $C$. fragaefolii in the different municipalities of Rio Grande do Sul without the occurrence of species overlap in the same crop (Fig 1). Aphis forbesi occurred only in the municipality of Ipê (Fig 1), where $C$. fragaefolii did not occur. The rate of occurrence of $C$. fragaefolii in the surveys conducted shows that the pest was constant in strawberry production systems in the different municipalities studied, predominating in $80 \%$ of the samples during the study period (Fig 1).

Differences in the dispersion behavior of $C$. fragaefolii and $A$. forbesi in the municipalities of Rio Grande do Sul may have influenced the occurrence of these species in the survey, varying from place to place. The predominance of one or another aphid species in strawberry crops may be related to climatic factors such as temperature, wind, and humidity as climatic factors and diet can directly influence the population dynamics of aphids in cultivated areas (Nickel 1987). Aphis gossypii was not observed in Rio Grande do Su and only rarely Paraná, although existing reports on its sporadic occurrence in Rio Grande do Sul (Salles 2003).

Chaetosiphon fragaefolii was a dominant species in study sites in the states of Rio Grande do Sul and Paraná as it has in the USA, Europe, South Africa, and Argentina (Krczal 1982, Rondon \& Cantcliffe 2004, Cédola \& Greco 2010). This pest is considered the major insect vector for viruses such as strawberry vein banding virus, strawberry mild yellow edge virus, strawberry crinkle virus, and strawberry mottle virus (Krczal 1982, Rondon \& Cantcliffe 2004, Cédola \& Greco 2010).

In our study, C. fragaefolii predominated and showed maximum indices of faunal classification as dominant, very abundant, very frequent, and constant totaling $68 \%$ of all insects identified, at both sites sampled (Rio Grande do Sul and Parana), while the others species $A$. forbesi, $A$. gossypii, $M$. persicae, and $T$. nigriabdominalis were classified as intermediate and rare (Tables 1 and 2 ) with $A$. gossypii, $M$. persicae, and $T$. nigriabdominalis occurring only in Pinhais.

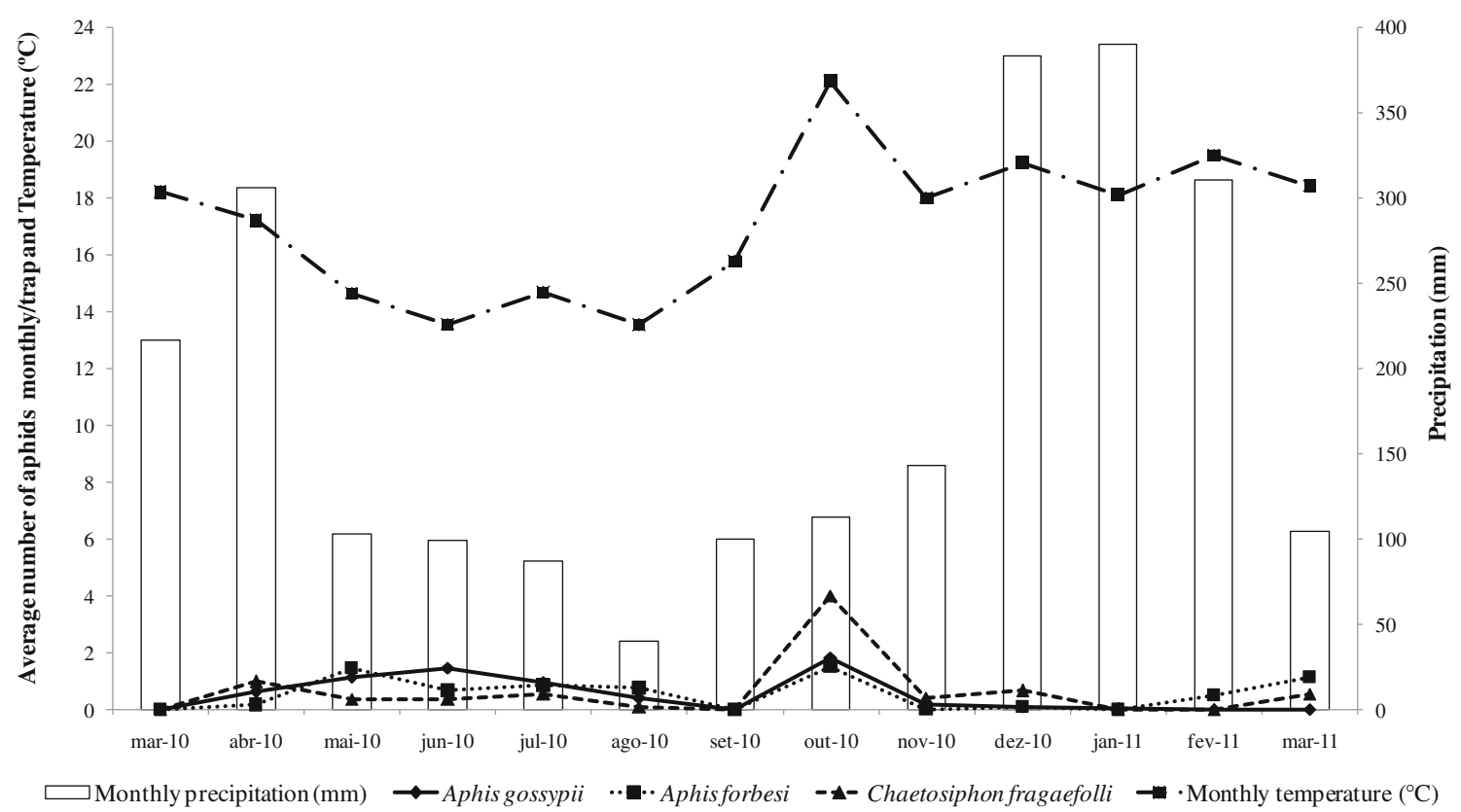

Fig. 2 Population dynamics of aphids (wingless + winged) using the Moericke trap in strawberry culture in the municipality of Pinhais, state of Paraná, Brasil. 
Species diversity in four cultivars and population dynamics in the state of Paraná

We did not find significant difference in aphid infestations (wingless+winged) for $A$. gossypii $(F=0.76 ;$ g.l. $=3.571$; $P=0.515), A$. forbesi $(F=2.16 ;$ g.l. $=3.571 ; P=0.191)$, and $C$. fragaefolii $(F=0.75 ; g . l=3.571 ; P=0.522)$ in the cultivars Albion, Camino Real, Camarosa, and Ventana. Our data showed that the infestation level did not vary during the experimental period regardless of the cultivar and species of aphid (Table 3), demonstrating that insects showed no preference for colonization. Although studies of Rondon et al (2005), Cédola \& Greco (2010), and Bernardi et al (2012) indicated differences in susceptibility of strawberry cultivars to the biological development of aphids; this difference was not observed in this study.

Population dynamics of aphids in strawberry culture in the municipality of Pinhais, state of Paraná

Abundance of the three major species of aphids was influenced by climatic conditions (temperature and precipitation; Fig 2) indicating that environmental conditions (temperature and precipitation) are important factors for the development and population dynamics of aphids in strawberry, and can positively or negatively affect the development of these insects (Rondon et al 2005). The study demonstrated that the temperature and precipitation showed a constant pattern in the population growth of aphid species, observing the highest population peaks during lower precipitation levels and higher temperatures (Fig 2), similarly to the studies of Rondon \& Cantliffe (2004) and Cédola \& Greco (2010) with C. fragaefolii in strawberry culture and $A$. gossypii in chrysanthemum cultures (Soglia et al 2002).

In general, we observed low incidence of aphids in strawberry fields with only one population peak (September to November) during the study period, which may be related to the vegetative growth and flowering of strawberries (Rondon et al 2005, Cédola \& Greco 2010). In the municipality of Pinhais, C. fragaefolii population peaked in October 2010, probably due to a combination of high temperature and low precipitation rates, as well as longer exposure to daylight (higher photoperiod), corraborated with the results obtained in Argentina, where the specie C. fragaefolii species was recorded on strawberry plants at two population peaks, with the first peaks in the autumn and the second in the spring (Cédola \& Greco 2010). However, the species $A$. forbesi and $A$. gossypii showed higher population peaks during the months of May and July 2010 similarly to the results obtained by Rondon et al (2005), who verified highest abundance of $A$. gossypii during the spring in strawberry cultivations in greenhouses. This fact may be related to the flowering of plants, leading the aphids the infest the plants in the parts that are more nutritious Valerio and Mexia (2007). Aphid infestation deceased after November most likely due to the low amount of new shoots and to the action of natural enemies (predators and parasitoids; Rondon et al 2005). Furthermore, the colonization behavior of A. gossypii and $A$. forbesi species affects the sampling of insects in strawberry plants and, therefore, the estimation of population density once they tend to aggregate in the inner parts of plant crowns.

Acknowledgments The authors wish to thank Conselho Nacional de Pesquisa CNPq/MAPA and PROext MEC/SESu for financial support.

\section{References}

Abreu PCOV, Nogueira CR (1989) Spatial distribution of Siphonophora species at Rio de Janeiro Coast Brazil. Ciên Cult 41:897-902

Bernardi D, Garcia MS, Botton M, Nava DE (2012) Biology and fertility life table of the green aphid Chaetosiphon fragaefolii on strawberry cultivars. J Insect Sci 12:1-8

Blackman RL, Eastop VF (2000) Aphids on the world's crops: an identification and information guide, 2nd edn. Wiley, New York, p 2, $475 \mathrm{p}$

Cédola C, Greco N (2010) Presence of the aphid Chaetosiphon fragaefolii on strawberry in Argentina. J Insect Sci 9:1-9

Costa CL, Eastop VF, Blackman RL (1993) Brazilian Aphidoidea: I. Key to families, subfamilies and account of the phylloxeridae. Pesq Agropec Bras 28:197-215

Fadini MAM, Pallini A, Venzon M (2004) Controle de ácaros em sistema de produção integrada de morango. Ciênc Rural 34:1271-1277

Ferla NJ, Marchetti MM, Gonçalves D (2007) Ácaros predadores (Acari) associados à cultura do morango (Fragaria sp., Rosaceae) e plantas próximas no Estado do Rio Grande do Sul. Biota Neotrop 7:1-8

Henz GP (2010) Desafios enfrentados por agricultores familiares na produção de morango no Distrito Federal. Hortic Bras 28:260-265

Hodson WEH (1937) On the synonymy and biology of the strawberry aphis, Capitophorus fragariae (Theobald, 1912). Bull Entomol Res 28:409-416, http://journals.cambridge.org/action/displayAbstract? fromPage $=$ online\&aid $=2514144$. Accessed: 9 Mar 2013

Krczal H (1982) Investigations on the biology of the strawberry aphid (Chaetosiphon fragaefolii), the most important vector of strawberry viruses. Acta Hort 129:63-68

Martin JH (1983) The identification of common aphid pest of tropical agriculture. Trop Pest Manag 29:395-411

Miller GL, Foottit RG (2009) The taxonomy of crop pests: the aphids. Insect biodiversity Science and Society, p 463-473

Miñarro M, Espadaler X, Melero VX, Suárez-Álvarez V (2009) Organic versus conventional management in an apple orchard: effect of fertilization and tree-row management on grounddwellings predaceous arthropods. Agr Forest Entomol 11:133-142

Nickel O (1987) Afídeos (Homoptera: Aphididae) da província de Misiones, Argentina. Pesq Agropec Bras 22:353-358

Remaudière G, Remaudière M (1997) Catalogue des Aphididae du monde of the world's Aphididae. Homoptera Aphidoidea, INRA Editions, $473 \mathrm{p}$

Rondon S, Cantcliffe D (2004) Chaetosiphon fragaefolii (Homoptera: Aphididae): A potential new pest in Florida? Fla Entomol 4:612-614 
Rondon S, Cantcliffe D, Price J (2005) Population dynamics of the aphid Aphis gossypii (Homoptera: Aphididae), on strawberry grown under protected structure. Fla Entomol 2:152-158

Salles L.A.B.. Pragas. In: FORTES, J. F.; OSÓRIO, V. A. (Ed). Morango Fitossanidade. Brasília: Embrapa, 2003. (Informação tecnológica, 36 p)

Sas Institute (2009) Statistical Analysis System: getting started with the SAS learning. $81 \mathrm{p}$

Soglia MCM, Bueno VHP, Sampaio MV (2002) Desenvolvimento e sobrevivência de Aphis gossypii Glover (Hemiptera: Aphididae) em diferentes temperaturas e cultivares comerciais de crisântemo. Neotrop Entomol 31:211-216
Valério E, Mexia CA (2007) Population dynamics of aphids (Homoptera: Aphididae) and beneficial organisms on protected strawberry crops. Bol Sanid Veg 33:153-161

Van Driesche RG, Heinz KM, Van Lenteren JC, Loomans A, Wick R, Smith T, Lopes $P$, Sanderson JP, Daughtrey M, Brownbridge $M$ (1998) Western flower thrips in greenhouses: a review of its biological control and other methods. U Mass Extension Floral Facts, University of Massachusetts, Amherst

Zehnder G, Gurr GM, Kuhne S, Wade MR, Whatten SD, Wyss E (2007) Arthropod pest management in organic crops. Annu Rev Entomol 52:57-80 